レーザーオリジナル

$\mathrm{Ag}, \mathrm{Cs}$ 添加による高温型銅蒸気レーザー出力特性の改善

\author{
木村 博信* ・原 一彦* ・ 飯島 智浩* ・ 名雪 玩弥* \\ 藤原 閲夫*・斉藤 弘 $* *$
}

(1996 年 1 月 29 日 受理)

\title{
Improvement of the Lasing Performance of Copper Vapor Laser by Adding Ag and/or Cs Atoms
}

\author{
Hironobu KIMURA*, Kazuhiko HARA*, Tomohiro IIJIMA*, Takuya NAYUKI*, \\ Etsuo FUJIWARA* and Hiroshi SAITOH**
}

(Received January 29, 1996)

\begin{abstract}
The lasing performance of a copper vapor laser (CVL) with $60 \mathrm{~mm}$ diameter and $2000 \mathrm{~mm}$ discharge length has been successfully improved by adding $\mathrm{Ag}$ and/or Cs atoms. As typical results, $33 \%$ increase of output power and wall-plug efficiency has been obtained. The upper laser level is enhanced by the collisional energy transfer from a response of $\mathrm{Ag}$ atoms to a resonance-excited state of $\mathrm{Cu}$ atoms. In addition, the effective relaxation of the lower laser level is appeared due to the collision of the second kind between the metastable $\mathrm{Cu}$ atoms and adding $\mathrm{Cs}$ atoms.
\end{abstract}

Key Words: CVL, Added Ag/Cs, Energy transfer, Laser level enhancement, Relaxation.

1.はじめに

銅蒸気をレーザー媒質とする高温型銅蒸気 レーザー(高温型CVL)は, 可視域で高出力・高効 率・高繰り返し発振可能なパルスレーザーであ る。最近, この可視域における高出力の利点を生 かし, CVLをレーザー同位体分離 ${ }^{1-2}$ ) 産業用精 密加工, 分光用光源として応用3)する試みがなさ
れている。CVLをこれら産業用に応用する場合， 高出力化や長寿命化もさることながら, 高効率 化による運転費の低減をはかることが必要であ る。CVLの高出力化に関しては, 放電長を伸長 する方式4)や口径を増大させる方式 5)で, 単機 500W以上の出力を得ている。長寿命化に関して は, パルス電源回路 6,7)に工夫をこらし，300 時 間以上の連続運転を可能にしている。一方, 高効

*レーザー濃縮技術研究組合（广 319-11 茨城県那珂郡東海村白方白根 2-76)

**岩手大学工学部電気電子工学科 (T 020 盛岡市上田 4 丁目 3 番 5 号)

* Laser Atomic Separation Engineering Research Association of JAPAN (2-76 Aza Shirane, Oaza Shirakata, Tokaimura, Naka-gun, Ibaraki 319-11)

* * Department of Electrical and Electronic Engineering, Iwate University (4-3-5 Ueda, Morioka, Iwate 020) 
率化に関しては，CVLは可視レーザーの中では 効率が高いことから, 特に高効率化にしぼった 研究開発は行われていない。一方, メタルハライ ドレーザーの一種である塩化銅蒸気レーザーや 臭化銅蒸気レーザー等の低温型銅蒸気レーザー （低温型CVL）に関しては，銅以外の金属蒸気を 導入することにより, 発振効率の向上ならびに 出力向上の研究がなされている ${ }^{8-12) 。 た と え は ゙, ~}$ $\mathrm{CuBr}$ レーザーに AgBr P CsBr を添加することに より出力及び効率共に $30 \sim 50 \%$ 程度の向上を得 た報告 ${ }^{8-9)}$ がある。一方, $\mathrm{CuCl}$ レーザーに Cs 蒸 気を導入すると発振パルス幅が倍増する実験事

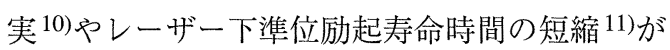

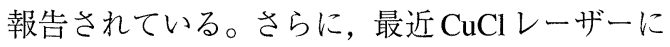
$\mathrm{Ag}$ と Cs を同時に添加し，2.8 倍の出力及び効率 の向上を得ている報告 ${ }^{11)}$ がある。

しかし，いままでこれら低温型CVLの成果を 高温型 CVLに適用した報告は見当らない。

そこで，われわれは，高温型 CVLに Ag, Csの 蒸気を単独及び複合させて添加し, 上記のよう に, 出力及び効率の向上が得られるかどうか初 めて実験的に確かめた。

\section{2. 原 理}

CVL は, 強い共鳴捕獲現象を生じる共鳴準位 をポンピングに利用し，レーザー動作の反転分 布状態は, その共鳴準位と下の準安定準位間に 生起させている。ポンピングの際にはこの準安 定準位は基底状態との間が禁制遷移であるため, 基底状態からの直接励起による原子の分布は非 常に少ない。従って, 瞬間的なパルス放電励起に より容易に反転分布状態を生じ誘導放出が得ら れる。しかし,レーザー下準位が準安定準位であ るため, 下準位に分布する原子数が誘導放出に より急増し, 数 $10 \mathrm{~ns}$ の短時間で反転分布は消滅 してしまう。いわゆる自己終端型の動作をする。 このように出力特性が制限される主要原因は, CVLのレーザー下準位が準安定状態で，その励 起寿命時間がレーザー上準位の励起寿命時間よ り極端に長いためである。従ってCVLの出力/効 率向上のためには, (1)上準位を占める原子数を増 加させる, (2)下準位を占める原子数を減少させ

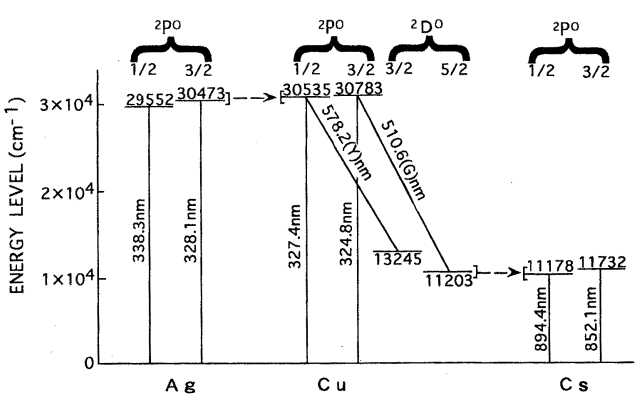

Fig. 1 Partial energy diagram of $\mathrm{Cu}, \mathrm{Ag}$ and $\mathrm{Cs}$ as well as relevant transitions(wavelength in $\mathrm{nm}$ ).

る,(3)(1)および(2)を同時に行う，ことが必要で ある。

CVLに $\mathrm{Ag}$ 又は $\mathrm{Cs}$ 蒸気を添加した場合の効果 を説明するために Fig. 1 に $\mathrm{Cu}, \mathrm{Ag}, \mathrm{Cs}$ の部分的 なエネルギーダイアグラムを示す。まず, CVLに $\mathrm{Ag}$ を添加した場合, $\mathrm{Ag}$ 原子はレーザー管の放電 により共鳴準位 $\left(29552 \mathrm{~cm}^{-1}\right.$ 及び $\left.30473 \mathrm{~cm}^{-1}\right)$ に 励起される。これらの励起銀原子は $\mathrm{Cu}$ の基底状 態原子とエネルギー移乗を伴う第 2 種衝突を生 じ， $\mathrm{Cu}$ のレーザー上準位 $\left(30535 \mathrm{~cm}^{-1}\right.$ 及び $30783 \mathrm{~cm}^{-1}$ ) の励起原子数を増大させる。この効 果は, Fig. 1に示すように, $\mathrm{Ag}$ の共鳴準位のエネ ルギー值が $\mathrm{Cu}$ のそれときわめて近く第2種衝突 の断面積が共鳴的に増大することによる。これ は $\mathrm{Ag}$ の蒸気を適量 $(\mathrm{Ag}$ 蒸気圧は $\mathrm{Cu}$ 蒸気圧の $1 / 10$ 程度 9,12$)) C V L$ に導入することにより前述 した(1)のレーザー上準位占有原子数を効果的に 増加させることにつながり, 結果的にレーザー 性能 (出力及び効率) が向上することになる。

次に, CVLにCs蒸気を添加した場合の効果に ついて考える。 $\mathrm{Cu}$ 原子のレーザー下準位（準安 定状態) は, 基底状態からそれぞれ13245, 11203 $\mathrm{cm}^{-1}$ 上にあり，この準位に分布する原子の寿命

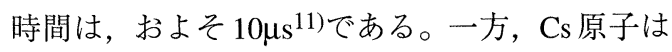
基底状態より $11178,11732 \mathrm{~cm}^{-1}$ 上に共鳴準位が 存在し寿命時間はそれぞれ〜 40, ～30nsである 15)。したがって, Cuレーザー下準位とCs原子の 共鳴準位間のエネルギー差が非常に小さく，基 底状態を占熱運動しているCs原子と準安定状 態を占めている銅原子が衝突すると, Fig. 1 に示 すようにCu原子からCs原子へエネルギー移乗を 生じ, 準安定状態の銅原子は基底状態に遷移し, 
代わりにCs 原子は共鳴準位に励起される。しか し，Cs原子のこのエネルギー準位に於ける平均 寿命時間は $30 〜 40 \mathrm{~ns}$ と非常に短いため, ただち に蛍光を放射して基底状態へ遷移する。以下こ の過程が繰り返され，レーザー下準位の平均寿 命時間が短くなる。これはとりもなおさず前述 (2)のレーザー下準位を占める原子数を減少させ ることに相当し, 結果的にレーザー性能 (出力及 び効率）が向上する。

以上述べた $\mathrm{Ag}, \mathrm{Cs}$ 添加の効果はそれぞれレー ザー上準位及びレーザー下準位に独立に働くも のと考えられ，同時に添加すれば，前述(3)のよ うにレーザー上準位粒子密度を増加させ，レー ザー下準位粒子密度を減少させる理想的な効果 が期待できる。

\section{3. 実験装置及び方法}

実験に使用した高温型CVLは，レーザー管内 径 $60 \mathrm{~mm}$, 放電長 $2000 \mathrm{~mm}$ のもので, その構造を Fig.2に示す。レーザー管には高純度アルミナ管 (ADS - 10, 純度 $99.9 \%$ 東芝セラミックス社製) を用い, その外周にアルミナファイバ熱絶縁材4) を巻いた後石英管で保持する。さらにその外周 を水冷された真空容器 (1部を電気絶縁のためセ ラミックブレークで分離し, 片側に陰極, 対向部
に陽極を取り付けさらにレーザー取り出し用空 を設けたもの) 中に封入したものである。アルミ ナ管, 断熱材, 石英管は, この真空容器の両端の フランジで2点支持固定されている。アルミナ管 温度はレーザー運転中常時高温 $\left(\sim 1500^{\circ} \mathrm{C}\right)$ で 保持される。励起用放電電源は, 通常のサイラト ロンを用いた容量移行型パルス電源にサイラト ロンの長寿命化のためフェライトコアを用いた 磁気アシスト回路を有するもの6)であり, 電気絶 縁されたセラミックブレークの両端にこれを接 続し陰極に負の高電圧高繰り返しパルス電圧 (立ち上がり $100 \mathrm{~ns}$ ，ピーク電圧〜 19kV) を印加 する。陽極は通常アース電位で使用する。充電コ ンデンサの容量は8nF，ピーキングコンデンサの 容量は $4 \mathrm{nF}$ とし充電電圧 $19 \mathrm{kV}$, 励起パルス繰り 返し数は $5 \mathrm{kHz}$ とした。

次に, $\mathrm{Ag}$ 及びCs原子の添加方法について述べ る。 $\mathrm{Ag}$ の添加は, 臭化銅蒸気レーザー等低温型 CVLの実験3)では, $\mathrm{CuBr}$ に $\mathrm{AgBr}$ を $10 \%$ 混合し た試料をレーザー管内に挿入している。この方 法は $\mathrm{CuBr}$ と $\mathrm{AgBr}$ の蒸気圧がほほ等しいため使 用できるが, 高温型CVLではこの方法は適用で きない。Fig. 3 に Ag, $\mathrm{Cs}, \mathrm{Cu}$ の温度に対する蒸 気圧の特性 ${ }^{13)}$ を示す。この図から明らかなよう に, $\mathrm{Cu}$ 蒸気と $\mathrm{Ag}$ 蒸気の混合比を制御するために は，それぞれの金属の周囲温度を制御する必要

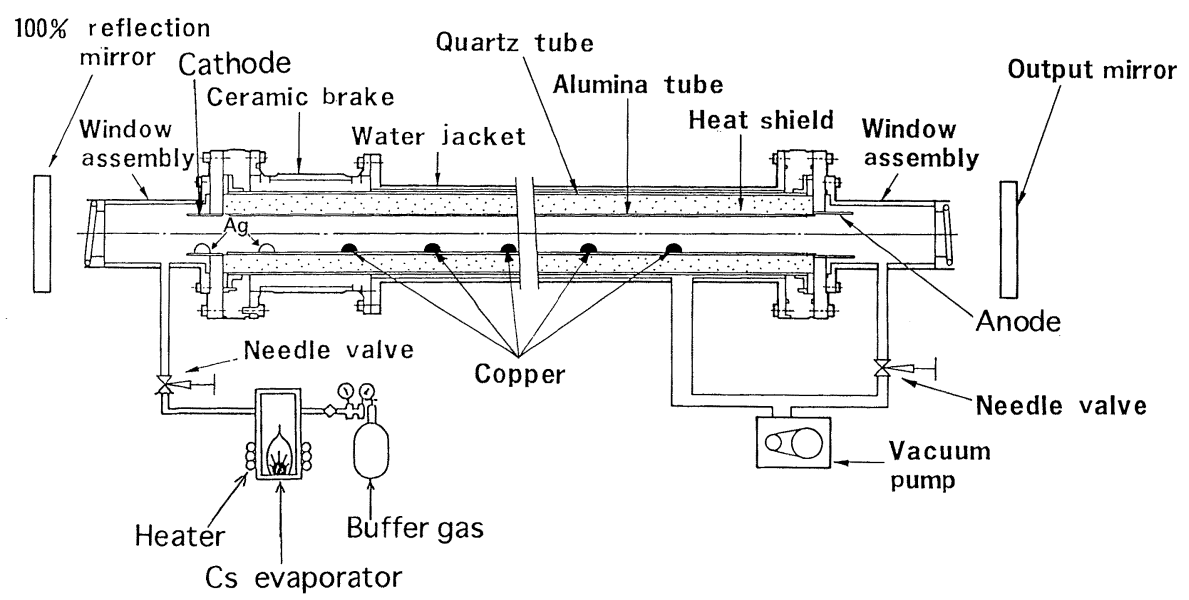

Fig. 2 Experimental CVL arrangement of improving the lasing performance by adding Ag and/or Cs atoms. 


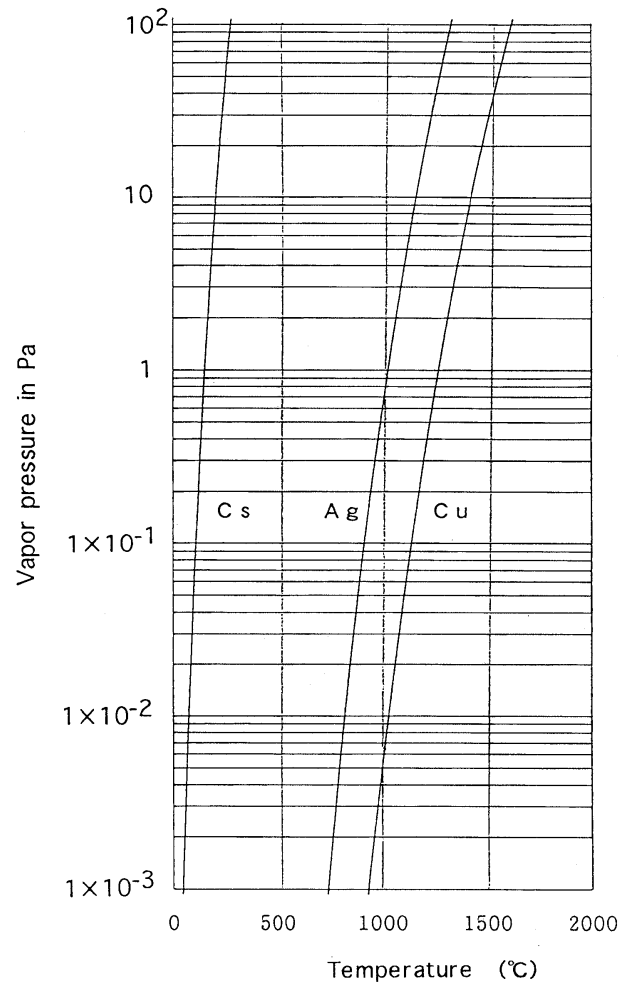

Fig. 3 Vapor pressure data for $\mathrm{Ag}, \mathrm{Cs}$ and $\mathrm{Cu}$.

がある。本実験では, $\mathrm{Ag}$ 蒸気圧制御のためレー ザー管内部の温度分布を利用して, Ag の温度を 制御している。すなわち,レーザー管端部におい ては，放射冷却によりレーザー管温度が低下す ることを利用し $\mathrm{Ag}$ をこの端部の最適温度の位 置に扱入し, 蒸気圧を制御する。尚, $\mathrm{Ag}$ の温度 はChinon IR-P3C放射温度計により非接触で測定 した。

次に, Cs 添加の方法は, 塩化銅蒸気レーザー 等では, レーザー管に $\mathrm{T}$ 型の枝管を設けて Cs 蒸 発器を取り付け, レーザー管内にCs 蒸気を導入 する方法 12)を用いている。高温型 CVL の場合 レーザー管温度が〜 $1500{ }^{\circ} \mathrm{C}$ と高温で上記の様な 枝管を設けることは技術的に困難であるため, Fig. 2 に示すようにレーザー管のバッファガス $\left(\mathrm{Ne}+0.5 \% \mathrm{H}_{2}\right)$ 導入路にヒーター付 Cs 蒸発器を 設置し, バッファガスを $5 \ell / \mathrm{h}$ の流量で注入する ことによりレーザー管内に Cs 蒸気を導入した。 Cs 蒸気圧は蒸発器外側に巻いたヒーター（最大
温度 $160^{\circ} \mathrm{C}$ ) で制御した。なお， Cs は大気にさら すとすぐ酸化するため，アンプルに封入した状 態で蒸発器に入れ十分真空排気しバッファガス に置換した後アンプルを割って実験に供するよ うにした。なお， $\mathrm{Ag}, \mathrm{Cs}$ 添加実験においては， レーザー管内バッファガス圧力は $3 \times 10^{3} \mathrm{~Pa}$ 一定 に保った。また,レーザー管はニードルバルブを 通じて, 常時排気されており, 添加金属蒸気が, 真空ポンプから大気中に排出されることを防止 するため, レーザー管と真空ポンプ間にアルミ ナファイバを充てんしたトラップを設けた。ま た, CVL共振器は, 誘電体多層膜コートの全反 射平面ミラー（反射率 $99 \%$ 以上）と片面無反射 コートの平行平面基板 (反射率 $4 \%$; レーザー出 カミラー)で構成した。レーザー発振光パルス波 形はバイプラナー光電管（浜松ホトニクス社製 R1193U) とオシロスコープ（テクトロニクス社 製 2445A）で，レーザー出力は精度 $\pm 5 \%$ 以内の レーザーパワーメーター（サイエンテック社製 モデル 360801）で測定した。

\section{4. 実験結果及び考察}

\section{1 $\mathrm{Ag}$ 添加実験}

$\mathrm{Ag}$ 蒸気压に対する出力依存性を調べるため, $\mathrm{Ag}$ の温度を変化させてレーザー出力特性を測定 した。 $\mathrm{Ag}$ 温度としては $700^{\circ} \mathrm{C}, 850^{\circ} \mathrm{C}, 1100^{\circ} \mathrm{C}$, $1300^{\circ} \mathrm{C}$ の 4 点で実験した。実験結果を Fig. 4 に示 す。この図から明らかなように $\mathrm{Ag}$ 添加において は, $\mathrm{Ag}$ 温度でかなりレーザー出力の変化が大き く, 温度 $1100^{\circ} \mathrm{C}$ の時に最も大きな添加効果が得 られた。添加 $\mathrm{Ag}$ 蒸気圧は, Fig. 3 の各金属の蒸 気圧特性から $\mathrm{Cu}$ の $10 \%$ 程度であり，低温型 CVLで得られている混合比とほぼ同等であった。

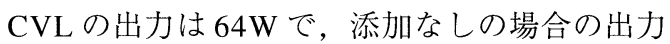
$57 \mathrm{~W}$ に比較して $12 \%$ (投入電力は添加条件によ らず一定の $7.2 \mathrm{~kW}$ であるため効率も $0.79 \%$ から $0.89 \%$ に改善）の向上が観測された。この時の レーザー出力光パルス波形を Fig. 5 に示す。この 実験データからレーザー出力波形は, パルス幅 が若干広がる傾向が見られた。今回得られた高 温型 CVLの結果では, レーザー出力及び効率の 向上が $\mathrm{Ag}$ 添加の場合 $12 \%$ であったが, 従来の低 


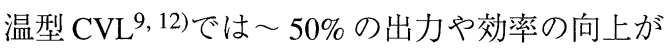
得られている。また,レーザー光パルスに関して は, 今回の高温型CVLでは半值幅が微増したが, 従来の低温型CVLでは明らかに光パルス幅が伸 長している。これらのことから, 高温型 CVLの $\mathrm{Ag}$ 蒸気添加は, 明らかに出力や効率などの性能 向上につながるものの，低温型CVLに比較する とその効果は $1 / 5$ 程度にとどまった。また, 高温 型CVLにAg原子を添加する実験では, 添加効果 がAg温度 (蒸気圧)に強く依存することがわかっ た。今回実験したパラメータの範囲では, Fig. 3, Fig. 4 より $\mathrm{Ag}$ 蒸気圧が, $\sim 4 \mathrm{~Pa}$ 程度 (高温型 $\mathrm{CVL}$ では $\mathrm{Cu}$ 蒸気圧は〜 40Pa) で添加の効果が見られ， 他の条件特に $\mathrm{Ag}$ 蒸気圧が $\mathrm{Cu}$ 蒸気圧の3倍に当た る $\mathrm{Ag}$ 温度 $1300^{\circ} \mathrm{C}$ ではレーザー出力が〜 $1 / 10$ 程度 に激減している。この理由は,レーザー媒体とな る $\mathrm{Cu}$ 原子数より添加の $\mathrm{Ag}$ 原子数が増大するこ とにより, 放電中の電子温度が低下し, $\mathrm{Cu}$ 原子 を十分に励起出来なくなるためと考えられる。 一方 $\mathrm{Ag}$ 添加量が $1 \%$ 以下の場合（Fig. 4 で， $\mathrm{Ag}$ 温度 $850^{\circ} \mathrm{C}$, 及び $\left.700^{\circ} \mathrm{C}\right)$ もレーザー出力が $\mathrm{Ag}$ 添 加前より多少小さくなっている。この理由は, $\mathrm{Ag}$ 蒸気圧が低いためにAg原子の共鳴準位における 共鳴捕獲現象が弱く, 励起状態の寿命時間が レーザー上準位の Cu原子の寿命時間 (615ns) ${ }^{11)}$ より短くなり，エネルギー移乗の方向が逆転す るためである。

このように高温型CVLにAgを添加して性能向 上をはかる場合, $\mathrm{Ag}$ 蒸気圧 $(\mathrm{Ag}$ 蒸発源温度)の

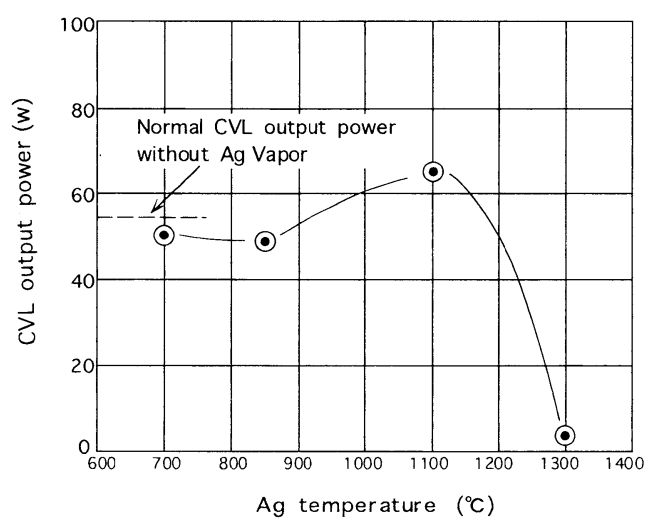

Fig. 4 CVL output characteristics by adding Ag atoms at various $\mathrm{Ag}$ temperaturesand pressure.

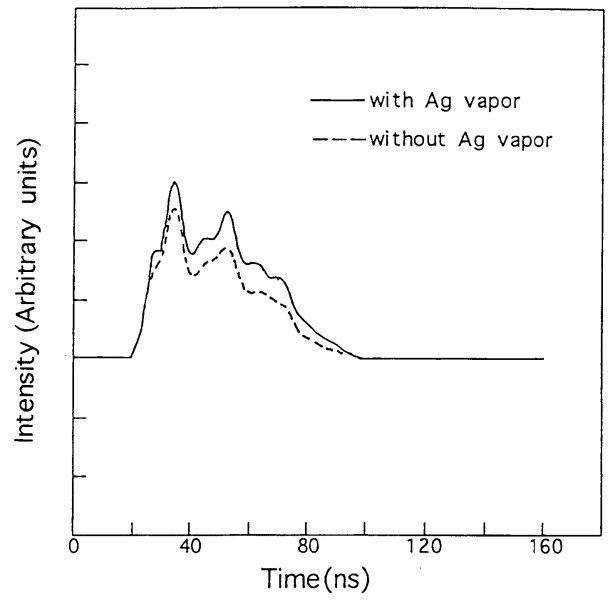

Fig. 5 Laser output temporal profiles with or without adding Ag vapor.

制御が重要であると思われる。

\subsection{Cs 添加実験}

Cs蒸気圧のレーザー出力依存性を調べるため, $\mathrm{Cs}$ 蒸発器の温度を $30^{\circ} \mathrm{C} \sim 160^{\circ} \mathrm{C}$ に変化させて高 温型 CVLの発振出力の測定を行った。Fig. 6 に レーザー出力とセシウム蒸発器の温度との関係 を示す。この結果から, Cs 添加の場合レーザー 管内部の $\mathrm{Cs}$ 密度換算で $10^{11}$ 個 $/ \mathrm{cm}^{3}(\mathrm{Cu}$ の蒸気 圧の〜 $1 / 10^{4}$ 程度) まで単調にCVL出力が向上す ることが示された。またCs添加によりセシウム 蒸発器温度 $160^{\circ} \mathrm{C}$ においてレーザー出力が $73 \mathrm{~W}$, 効率が $1.0 \%$ となり最大 $28 \%$ の出力及び効率の 向上が見られた。またこの時のレーザー出力光 パルス波形を Fig. 7 に示す。この実験データから レーザー出力波形はCs 添加によりパルス幅が広 がっていることが明らかとなった。今回得られ た高温型 CVLへの Cs 添加実験結果では, レー ザー出力及び効率の向上が最大で $28 \%$ であった が, 低温型 CVLでは, 出力及び効率が $1.3 \sim 7$ 倍 8, 10) となっている。一方, レーザー発振パルス幅 は, 高温型CVLでは 20\%の伸長が得られたのに 対し, 低温型CVLでは, 〜 4倍に伸長している。 これらの結果から, 高温型 CVLの Cs 蒸気添加は 明らかに出力／効率などの性能向上につながる ものの低温型CVLに比較するとその効果はかな り低下することがわかった。本実験において，よ 
り大きな $\mathrm{Cs}$ 添加密度領域に関しては, Cs 蒸発器

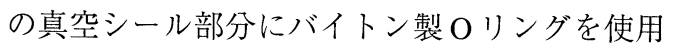
したためその耐熱温度 $160^{\circ} \mathrm{C}$ 以上に昇温出来な かったことを付記しておく。

\subsection{Ag, Cs 同時添加実験}

高温型CVLでAg, Csを同時に添加した場合の 性能向上特性を測定するため, CVLレーザー管 内温度 $1100^{\circ} \mathrm{C}$ の位置に $\mathrm{Ag}$ を挿入し, レーザー発 振出力が飽和した後, Cs 蒸発器内のCs アンプル を割って加熱を開始し, 蒸発器温度が $160^{\circ} \mathrm{C}$ に達 するまで測定を行った。これらの条件は, $\mathrm{Ag}, \mathrm{Cs}$ の添加蒸気圧がそれぞれの最適動作条件となる 值に設定したものである。この実験時のレー ザー出力チャートをFig. 8に示す。この図から明 らかなように，まずAg添加の効果が明白に現れ， その後Cs蒸気圧の上昇とともにCVLの出力が向 上した。Oリング耐熱限界のため Cs 蒸発器温度 が $160{ }^{\circ} \mathrm{C}$ に達した時点で実験を中止したが, 最終 的にレーザー出力は $76 \mathrm{~W}$ 発振効率は $1.1 \%$ とな り, 添加なしに比較して $33 \%$ の出力及び効率向 上が観測された。この結果から, $\mathrm{Ag}, \mathrm{Cs}$ を同時 添加した場合それぞれの効果がほぼ加算されて あらわれることがわかった。一方, 低温型 CVL

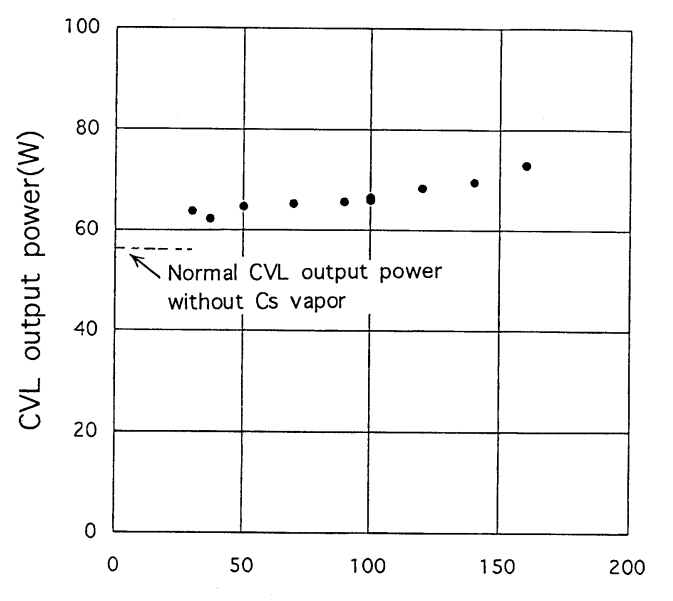

Cs evaporator temperature $\left({ }^{\circ} \mathrm{C}\right)$

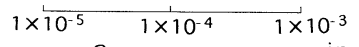

Cs vapor pressure in $\mathrm{Pa}$

Fig. 6 CVL output power by adding Cs atoms at various Cs temperatures.

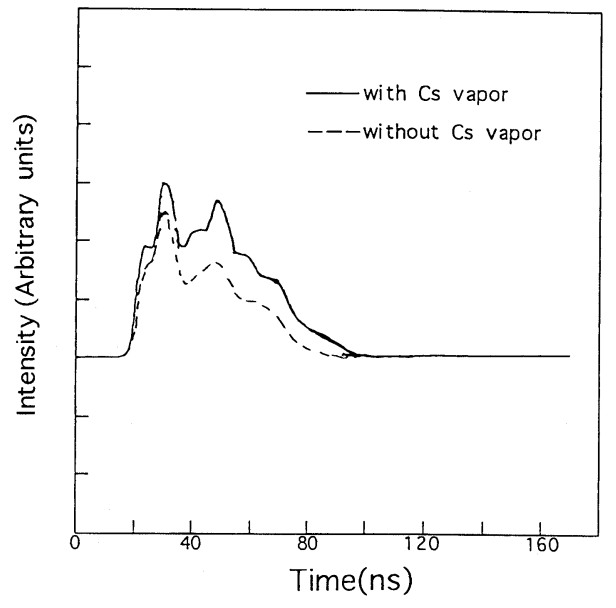

Fig. 7 Laser output temporal profiles with or without adding Cs vapor.

に扔ける同様の実験11)では，レーザー出力が同 時添加の効果で 2.8 倍に上昇している。この実験 結果からも高温型 CVLの場合, $\mathrm{Ag}, \mathrm{Cs}$ の同時添 加効果は観測されるもののその効果は, 低温型 CVLの 1/10 程度となっている。また高温型 CVL では, $\mathrm{Ag}$ 添加出力に対してCs 添加による出力及 び効率向上は $19 \%$ なのに対し, 同様の低温型 CVLに対する性能向上は 2 倍となっている。こ こでも高温型CVLの添加効果は低温型のそれに 比較して $1 / 10$ 程度になっている。またレーザー 出力は, $\mathrm{Ag}, \mathrm{Cs}$ などの蒸気の導入に対しては安 定で, 放電等の不安定現象は観測されなかった。

\section{4 実験結果のまとめ}

以上述べたように, 高温型CVLに Ag, Csの蒸 気を添加し性能を向上する実験を行い, $\mathrm{Ag}$ 添加 で $12 \%$ の出力及び効率の向上が得られ, Cs 添加 では 28\%の出力及び効率の向上が得られた。さ らに, $\mathrm{Ag}$ 及びCsを同時に添加した場合は $33 \%$ の 出力及び効率向上が得られた。これらの実験結 果をTable Iにまとめた。

この結果を臭化銅蒸気レーザーや塩化銅蒸気 レーザー等低温型CVLにおける同種の添加実験 と比較すると, その効果がかなり減少している ことがわかった。 $\mathrm{Ag}$ 及び $\mathrm{Cs}$ の添加による $\mathrm{CVL}$ 性能向上の原理として, 前述したように原子間 における第 2 種衝突によるエネルギー移乗があ 


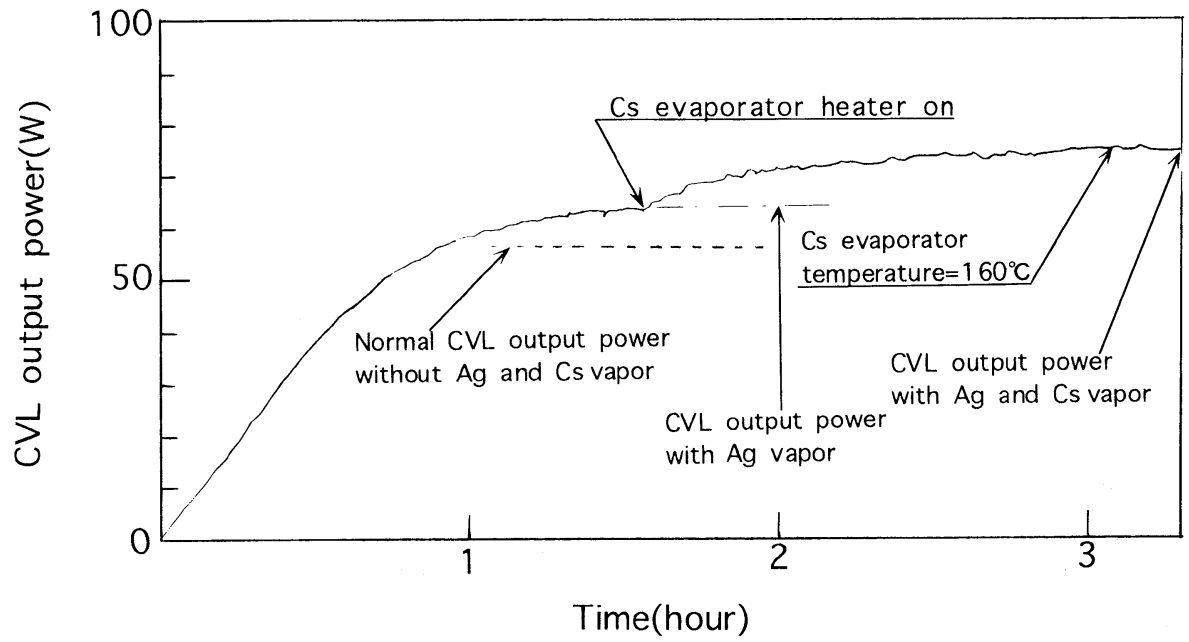

Fig. $8 \mathrm{CVL}$ output power by adding $\mathrm{Ag}$ and/or Cs atoms.

げられる。この衝突周波数が，高温型 CVL と低 温型 CVL で大きく異なる実験条件の一つであ る。レーザー管の動作温度に関して衝突周波数 がどのように変化するか以下に考察する。マク スウェルーボルツマン分布を有する気体系の原 子間衝突では，粒子間の衝突周波数 $v_{\mathrm{c}}{ }^{14)}$ は

$$
v_{\mathrm{c}}=\frac{4 \sqrt{\pi} P d^{2}}{\sqrt{m k T}} \propto \frac{P}{\sqrt{T}}
$$

で示される。ここで， $d$ は原子直径， $m$ は質量， $k$ はボルッマン定数, $P$ は圧力, $T$ は絶対温度で ある。この式は, 単一原子モデルの時に成立する 式であり, 実際は多体衝突問題でありこの式ほ ど単純化できないが, 高温型 CVLと低温型 CVL の第 2 種衝突頻度の傾向を評価するには十分と 考えられる。高温型CVLも低温型CVLも添加金 属原子の分圧には大きな差はなく, レーザー管 動作温度Tだけが大きく異なっている。(1)式に代 表的な低温型 $\mathrm{CVL}$ の動作温度 $300^{\circ} \mathrm{C}$ (絶対温度 では 573K）及び高温型 CVL の動作温度 $1500^{\circ} \mathrm{C}$ （絶対温度では $1773 K ） を$ を代入し, 高温型 CVLと 低温型 CVL の衝突周波数の比を求めると, 約 $1 / 2$ となる。したがって, 高温型 CVLは低温型 CVLに比較して添加効果が小さくなると考えら れる。

さらに, 今回実験に使用した高温型 CVLの レーザー管口径は，60mm と大口径であり，（引
用した低温型CVLの口径は $12 \sim 26 \mathrm{~mm}$ と小口径 である) Kushnerら 15)によれば, 高温型レーザー 管中心部のガス温度は, 3000Kを越えることも報 告されている。したがって, 上記試算よりさらに 衝突周波数が低減すると考えられる。また,この 中心部のガス温度の上昇により, 放電アフター グロー中 $\mathrm{Cu}$ のレーザー下準位 (準安定準位)に 熱的に励起された粒子が 16)一定量存在しており, $\mathrm{Cs}$ 等の添加効果を弱める要因にもなっていると 考えられる。さらに, Cs 原子の第一イオン化エ ネルギーは, $3.89 \mathrm{eV}$ と小さので, 高温型 CVL では，実質的にエネルギー移乗現象に関与でき る中性原子数が減少している。高温型 CVLに $\mathrm{Ag}, \mathrm{Cs}$ を添加し, 出力及び効率等の性能向上が 実現されたが, その効果は, 低温型 CVLで観測 されたようなドラスティックな効果は期待でき ないことがわかった。

\section{5. おわりに}

口径 $60 \mathrm{~mm}$, 放電長 $2000 \mathrm{~mm}$ の高温型 CVLに, $\mathrm{Ag}$ 及びCsを添加して, 出力及び効率を向上させ る試みを初めて行った。その結果, $\mathrm{Ag}$ 単独添加 で $12 \%$, Cs 単独添加で $28 \%, \mathrm{Ag}$ と Cs を同時に 添加することにより，33\%の出力及び効率の向 上が得られた。しかし, この効果は, 先に報告さ れている低温型CVLの実験結果よりかなり小さ 
Table I Typical experimental results of lasing performance of CVL by adding Ag and/or Cs atoms.

\begin{tabular}{|c|c|c|c|c|c|}
\hline \multirow{2}{*}{$\begin{array}{l}\text { Adding } \\
\text { atoms }\end{array}$} & \multicolumn{2}{|c|}{$\begin{array}{l}\text { Average total power } \\
\text { (Wall-pulg efficiency) }\end{array}$} & \multirow{2}{*}{$\begin{array}{l}\text { Output power/ } \\
\text { efficiency } \\
\text { increase } \\
(\%)\end{array}$} & \multirow{2}{*}{\multicolumn{2}{|c|}{ Experimental parameters }} \\
\hline & $\begin{array}{l}\text { Without adding } \\
\text { atoms }\end{array}$ & $\begin{array}{l}\text { With adding } \\
\text { atoms }\end{array}$ & & & \\
\hline $\mathrm{Ag}$ & $\begin{array}{c}57 \mathrm{~W} \\
(0.79 \%)\end{array}$ & $\begin{array}{c}64 \mathrm{~W} \\
(0.89 \%)\end{array}$ & $12 \%$ & $\begin{array}{l}\text { Charging voltage } \\
\text { Storage capacitance }\end{array}$ & $\begin{array}{l}: 19 \mathrm{kV} \\
\mathrm{e}: 8 \mathrm{nF}\end{array}$ \\
\hline Cs & $\begin{array}{c}57 \mathrm{~W} \\
(0.79 \%)\end{array}$ & $\begin{array}{c}73 \mathrm{~W} \\
(1.0 \%)\end{array}$ & $28 \%$ & $\begin{array}{l}\text { Repetition rate } \\
\text { Input electrical power }\end{array}$ & $\begin{array}{l}: 5 \mathrm{kHz} \\
: 7.2 \mathrm{~kW}\end{array}$ \\
\hline $\mathrm{Ag}+\mathrm{Cs}$ & $\begin{array}{c}57 \mathrm{~W} \\
(0.79 \%)\end{array}$ & $\begin{array}{c}76 \mathrm{~W} \\
(1.1 \%)\end{array}$ & $33 \%$ & $\begin{array}{l}\text { Buffer gas } \\
\text { Pressure }\end{array}$ & $\begin{array}{l}: \mathrm{Ne}(99.5 \%)+\mathrm{H}_{2}(0.5 \%) \\
: 30 \mathrm{mb}\end{array}$ \\
\hline $\mathrm{Zn}$ & $\begin{array}{c}57 \mathrm{~W} \\
(0.79 \%) \\
\end{array}$ & $\begin{array}{c}59 \mathrm{~W} \\
(0.82 \%) \\
\end{array}$ & $4 \%$ & $\begin{array}{l}\text { Flow rate } \\
\text { Operating temperature }\end{array}$ & $\begin{array}{l}: 5 \ell / \mathrm{h} \\
: 1500^{\circ} \mathrm{C}\end{array}$ \\
\hline
\end{tabular}

かった。この理由として,(1)高温型 CVL の動作 温度 $\left(\sim 1500^{\circ} \mathrm{C}\right)$ が低温型のもの $\left(\sim 300^{\circ} \mathrm{C}\right)$ に 比較してかなり高いこと,(2)使用した高温型CVL の口径が60mmと大口径であるため, 放電による レーザー中心部のガス温度が上昇し，これによ りレーザー下準位が熱的に励起された状態であ ることや添加 Cs のイオン化が進んでいること， などが考えられる。

また, $\mathrm{Ag}$ 添加に関しては, 最適添加濃度が $\mathrm{Cu}$ の $10 \%$ 程度であるため, レーザー管内に $\mathrm{Ag}$ と $\mathrm{Cu}$ の蒸気濃度比を一定に保つための制御がかなり 難しいことがわかった。一方Cs蒸気添加に関し ては，Csが大気中で自然発火するため，アンプ ルに封入した状態でCs蒸発器に入れ真空排気し ガス置換した後に外部よりアンプルを破壊して 蒸気を発生する操作が必要となった。また, 添加 蒸気がレーザー管通過後真空ポンプより大気中 に排出されることを防止するため，セラミック ウールを充てんしたトラップをレーザー管と真 空ポンプの間に設ける必要があった。

今回の実験で, 高温型 CVLでも $\mathrm{Ag}, \mathrm{Cs}$ 等の添 加効果があることがわかったので，今後より便 利な蒸気圧制御方法の開発や，添加金属が長期 にわたりCVLに与える影響（装置寿命等）を評 価したいと考えている。

\section{謝 辞}

実験全般にわたって協力して戴いた，レー
ザー濃縮技術研究組合の森岡昇氏, 佐藤康彦氏, 森秀夫氏, 天野治氏, 小松幸男氏, 川崎聡子氏に 謝意を表します。

\section{参 考 文 献}

1) J. L. Emmett, W. F. Krupke and J.I.Davis: IEEE J. Quantum Electron. QE-20 (1984)591.

2) N. Morioka: Proc. SPIE Laser Isotope Separation, Los Angeles California, 1993 (SPIE vol. 1859, Washngton, 1993) P2.

3) M. Nikonchuk: Proc. SPIE Gas and Metal Vapor Laser and Application, Los Angeles-California, 1991 (SPIE vol. 1412, Washington, 1991) P38.

4) H. Kimura, N. Aoki, C. Konagai, S. Shirayama and T. Miyazawa: J. Nucl. Sci. Tec. 31 (1994) 34.

5) 木村博信, 飯塚静夫, 小長井主税, 青木延忠 小林徳康, 馬場洋介：レーザー学会第 15 回 年次大会予稿集 (1995 年 1 月).

6) H. Kimura, R. Otani, N. Aoki, C. Konagai, S. Shirayama and T. Miyazawa: Rev. Laser Eng. 23 (1995) 210.

7) 高橋知幸, 木村博信：日本原子力学会誌 32 (1990) 476.

8) S. Sakata, K. Oohori, M. Higuchi, K.Fujii, K. Oouchi, S. Ueguri, Y. Ueda, S.Takemori, T. Sato and H. Saitoh: IEEE J.Quantum Electron 30 (1994) 2166.

9) K. Oouchi, M. Suzuki and K. Fujii: IEEE J. Quan- 
tum Electron 27 (1991) 2473.

10) H. Saitoh and H. Taniguchi: Appl. Phys. Lett. 47 (1985) 440.

11) 斉藤弘，大槻寿枝：レーザー研究 20 (1992) 777.

12) Y. Masumura, T. Ishikawa, H. Saitoh, M. Ishibashi and K. Fujii: Appl. Phys. Lett. 64 (1994) 3380.

13) 日本金属学会編：金属データブック改訂 2

\section{（丸善，東京，1984）P.82}

14) 電気学会編：放電ハンドブック改訂 5 (オー 么社, 東京, 1984) p.5.

15) M. J. Kushner and B. E. Warner: J. Appl. Phy. 54 (1983) 2970.

16) Y. Iseki, I. Hayashi, E. Watanabe, E.Noda and S. Suzuki: Jpn. J. Appl. Phys. 33 (1994) L860. 